TECHNICAL TRANSACTIONS 1/2017

CZASOPISMO TECHNICZNE $1 / 2017$

CIVIL ENGINEERING

DOI: $10.4467 / 2353737 X C T .17 .004 .6101$

\author{
Alicja Kowalska-Koczwara (alicja.kowalska.koczwara@gmail.com) \\ Krzysztof Stypuła \\ Institute of Structural Mechanics, Faculty of Civil Engineering, Cracow University \\ of Technology
}

\title{
A COMPARATIVE ANALYSIS OF TWO METHODS FOR DETERMINING THE INFLUENCE OF VIBRATIONS ON PEOPLE IN BUILDINGS
}

ANALIZA PORÓWNAWCZA DWÓCH METOD OKREŚLANIA WPEYWU DRGAŃ NA LUDZI W BUDYNKACH

\begin{abstract}
Different methodologies for the assessment of the influence of vibrations on people residing in buildings can be found in international standards. There are two dominant methods of assessment: the analysis of the RMS values in 1/3 octave bands and vibration dose VDV. In this article, these two methods of assessing the influence of vibration on humans are compared, not only on the basis of standard formulas but also on a real example. The influence of transport vibrations (busses, trams, trucks) on humans residing in traditional, masonry buildings was analysed. Conclusions resulting from a comparative analysis of the two methods of evaluation were formed.
\end{abstract}

Keywords: passive perception of vibration, vibration dose, RMS analysis, 'in-situ' measurements, transport vibrations

\section{Streszczenie}

W normach światowych można znaleźć różne metodyki służące ocenie wpływu drgań na ludzi przebywających w budynkach. Dominują dwie metody ewaluacji: analiza RMS w pasmach 1/3 oktawowych oraz dawka (doza) wibracji VDV. W niniejszym artykule obydwie metody oceny wplywu drgań na ludzi zostaly porównane nie tylko na podstawie zapisów normowych, ale także na konkretnym przykładzie. Analizie poddano wplyw drgań komunikacyjnych (przejazd autobusu, tramwaju, samochodu ciężarowego) na ludzi w budynku wykonanym w technologii tradycyjnej, murowanej. Sformułowano wnioski, które wynikają z analizy porównawczej dwóch metod ewaluacyjnych.

Słowa kluczowe: bierny odbiór drgań, dawka wibracji, analiza RMS, pomiary „in-situ”, drgania komunikacyjne 


\section{Introduction}

People residing in buildings are often exposed to dynamic influences, especially those of paraseismic origin. More and more dense urban building brings paraseismic vibration sources, mainly transport vibration sources, closer to buildings. The intensity of these dynamic influences increases because of much higher numbers of road users and much faster trains. In the diagnosis and design of buildings, there is a growing need to take into account these influences by analysing the ability to provide the necessary vibration comfort for residents. Vibration comfort cannot be exceeded. There are three main methods to assess vibration comfort:

a) corrected value - in which the assessment parameter is the acceleration (velocity) of vibration corrected across the whole frequency range;

b) RMS values - spectrum (frequency structure) of the effective value of acceleration (velocity) of vibration in $1 / 3$ octave band;

c) $V D V$ vibration dose - probability of complaints.

The corrected value (present in standards $[1,3]$ ) is determined by measuring the vibration at the location where it is perceived by humans using correction by means of a correction filter. The measurement information is expressed by one number. This number is compared with the corresponding value of providing the necessary vibrational comfort to people in the building. The application of the corrected value in the evaluation of vibration influence on people is relatively small. The frequency and degree to which the reduction of vibration should be introduced in order to ensure people the necessary vibration comfort cannot be determined on the basis of the corrected value - the researcher only knows whether or not the comfort level is exceeded. For these reasons, the corrected value will not be analysed later in this study - is becoming less common in international studies.

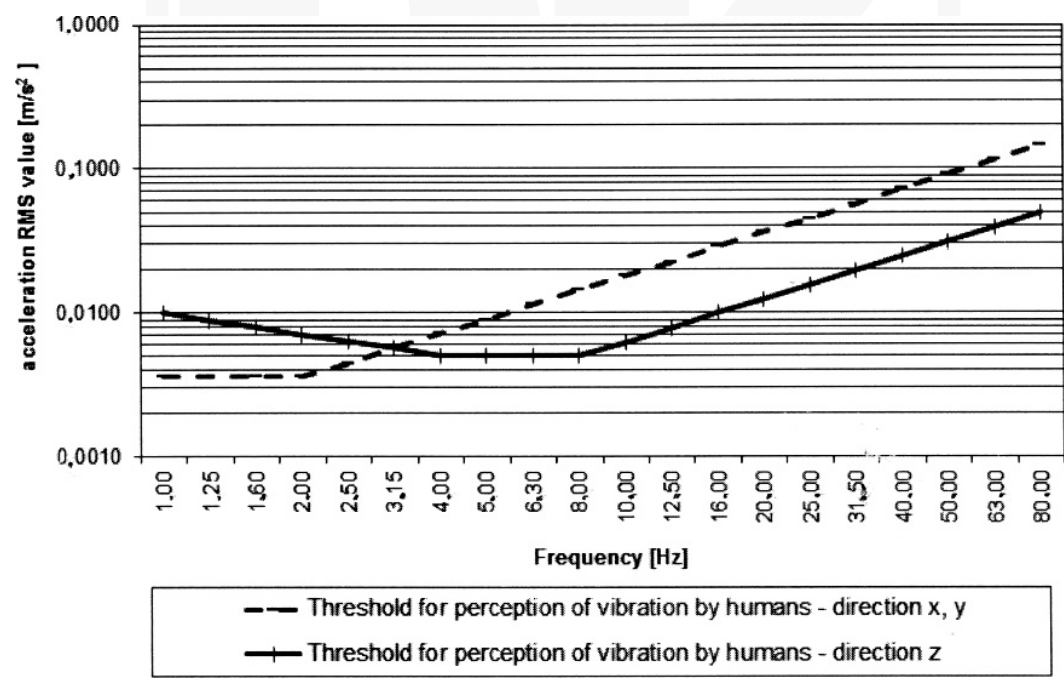

Fig. 1. Basic lines corresponding to the threshold for perception of vibration by humans (according to ISO 2631-2 [4] or Polish standard PN-88 / B-02171 [1]) 
The basic method of evaluation in the world is RMS - this evaluation parameter is adopted, for example, in standards $[1,4,5]$ and used by many researchers [e.g. 6-9]. From this method of evaluation, we can receive information concerning not only whether or not the comfort level is exceeded, but also within which frequency band any exceedance has occurred. This information can be obtained by comparing the frequency structure of the measured frequency curve with the corresponding frequency providing the necessary comfort of vibration to people in the building. Comfort level, what was written earlier, should not be exceeded. Sometimes, in the experts opinion, it tends to not exceed the threshold for perception of vibration. The threshold for the perception of vibration in both horizontal and vertical directions is shown in Fig. 1.

The basic levels for determining the level of vibration comfort are shown in Fig. 1. To identify lines that represent the vibration comfort threshold for the perception of vibration, lines should be multiplied by the appropriate value of factor ' $n$ ' (see Table 3 acc. [1]). This ' $n$ ' factor depends on:

- the purpose of the room in the building (e.g. operating theatres, precision laboratories, hospitals, apartments, residential rooms, offices, classrooms, workshops, factories etc.);

- the time of the occurrence of the vibration (daytime or night-time);

- the nature of vibrations and the frequency of their occurrence (continual or sporadic vibrations).

Sometimes, investors have stricter regulations then just conformity to accepted comfort levels or remaining within the thresholds of the perception of vibration by humans. For example, in the regulations of the Warsaw Metro, the value of the human vibration perceptivity ratio (named in Polish: WODL) should not exceed 0.85. The WODL ratio (in English, the human vibration perceptivity ratio - HVPR), proposed by K. Stypuła [10], is the measure of vibration perception by people. It is the maximum ratio of the acceleration $R M S$ value obtained from the analysis to the acceleration $R M S$ value equivalent to the threshold for the perception of vibration by humans (in the same $1 / 3$ octave band) chosen from each $1 / 3$ octave band (formula 1).

$$
W O D L=\max \left(\frac{a R M S}{a_{z}}\right)
$$

where:

aRMS - acceleration RMS value obtained from analysis;

$a_{z}$ - acceleration $R M S$ value equivalent to the threshold for the perception of vibration in a $\mathrm{z}$-direction in the same $1 / 3$ octave band as in aRMS.

This factor is very useful; however, because the graph adopts a logarithmic scale, it is often difficult to read by how much the threshold has been exceeded, or even if it has been exceeded at all (see Fig. 2).

The third of the applied parameters of the characteristics of vibration allows the effect of vibration on the inhabitants of buildings to be analysed by reference to the full-time assessment of the impact of vibration. The introduction of a value defined as the vibrations dose for the assessment of the influence of vibration on people allows the assessment of vibrations 


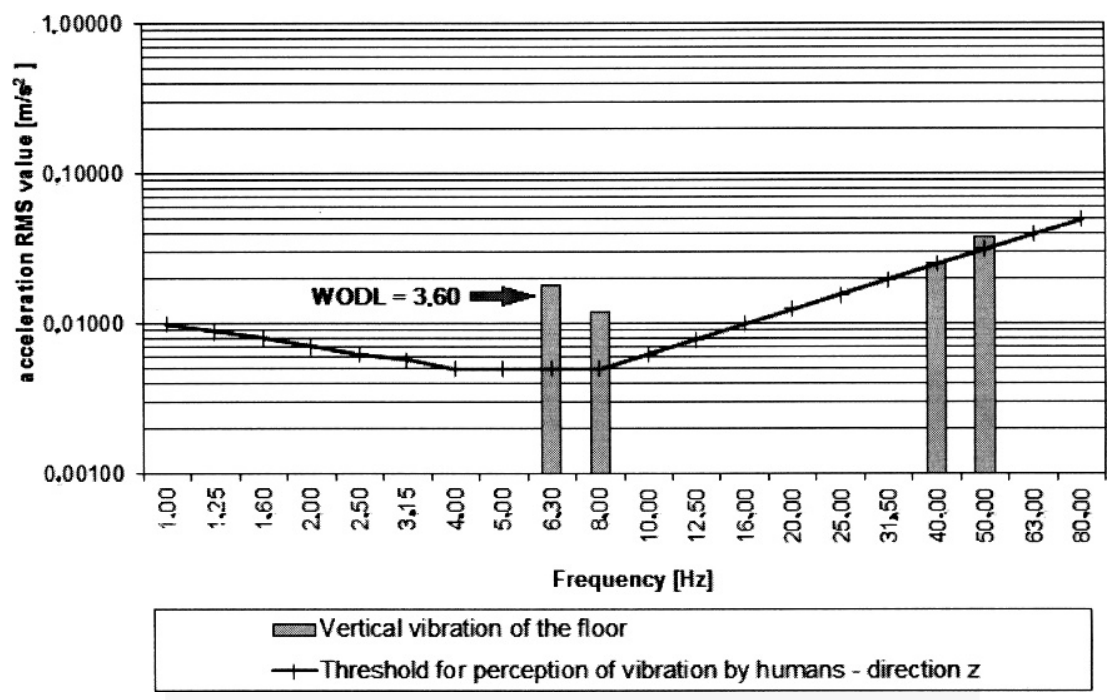

Fig. 2. Determination of human vibration perceptivity ratio (WODL)

of varying duration and repetition (continuous, intermittent, impulse). Vibrations are considered during the entire period of human exposure to vibration. In standard [2], vibration dose is denoted as $V D V$ and expressed in $\left[\mathrm{m} / \mathrm{s}^{1,75}\right]$ - this is given by the formula:

$$
V D V=\left\{\int_{0}^{t}\left[a_{w}(t)\right]^{4} d t\right\}^{1 / 4}
$$

where:

$a_{w}(t)$ - frequency-weighted acceleration;

$T$ - duration of measurement.

The fourth power vibration dose method is more sensitive to peaks than the RMS method and this is why $V D V$ is mostly used in shock analysis [11, 12]. In standard [4], the VDV method is defined as an additional method in cases when the crest factor is higher than 9. While in British Standard [2], VDV is the only method of evaluation. RMS method is also used in design see, for example, $[10,13]$.

The value of the vibration dose (VDV) determined from the above formula is compared with the values given in standards $[2,4]$. In table 1 , the three levels of probability of complains are given according to standards $[2,4]$.

Table 1. Criteria for assessing the influence of vibrations depending on the value $V D V\left[\mathbf{m} / \mathbf{s}^{1,75}\right]$

\begin{tabular}{|c|c|c|c|}
\hline Place & $\begin{array}{c}\text { Low probability } \\
\text { of adverse comments }\end{array}$ & $\begin{array}{c}\text { Adverse comments } \\
\text { possible }\end{array}$ & $\begin{array}{c}\text { Adverse comments } \\
\text { probable }\end{array}$ \\
\hline $\begin{array}{c}\text { Residential buildings } \\
-16 \mathrm{~h} \text { day }\end{array}$ & $0.2-0.4$ & $0.4-0.8$ & $0.8-1.6$ \\
\hline $\begin{array}{c}\text { Residential buildings } \\
-8 \mathrm{~h} \text { night }\end{array}$ & 0.13 & 0.26 & 0.51 \\
\hline
\end{tabular}


As can be seen from the above table, the value of $V D V$ gives an answer for the question: if there will be any complaints from residents. The aspect of complaints is important for investor. $V D V$ gives no information about the degree to which the occurring vibrations influence people. Unfortunately, nothing is known about which frequency must be reduced; this is why this method is not good for design and is only used as an additional method in the ISO standard.

\section{Description of the analysed building}

The building selected for analysis is located in Warsaw near two kinematic excitation sources:

- a road with heavy traffic located about $20 \mathrm{~m}$ from the building;

- a tramway located about $30 \mathrm{~m}$ from the building (distance measured from the railhead).

It is building with residential premises and offices. This is a five-storey building built using traditional brick technology that is typical in Poland (see Fig. 3) with a longitudinal arrangement of load-bearing walls.

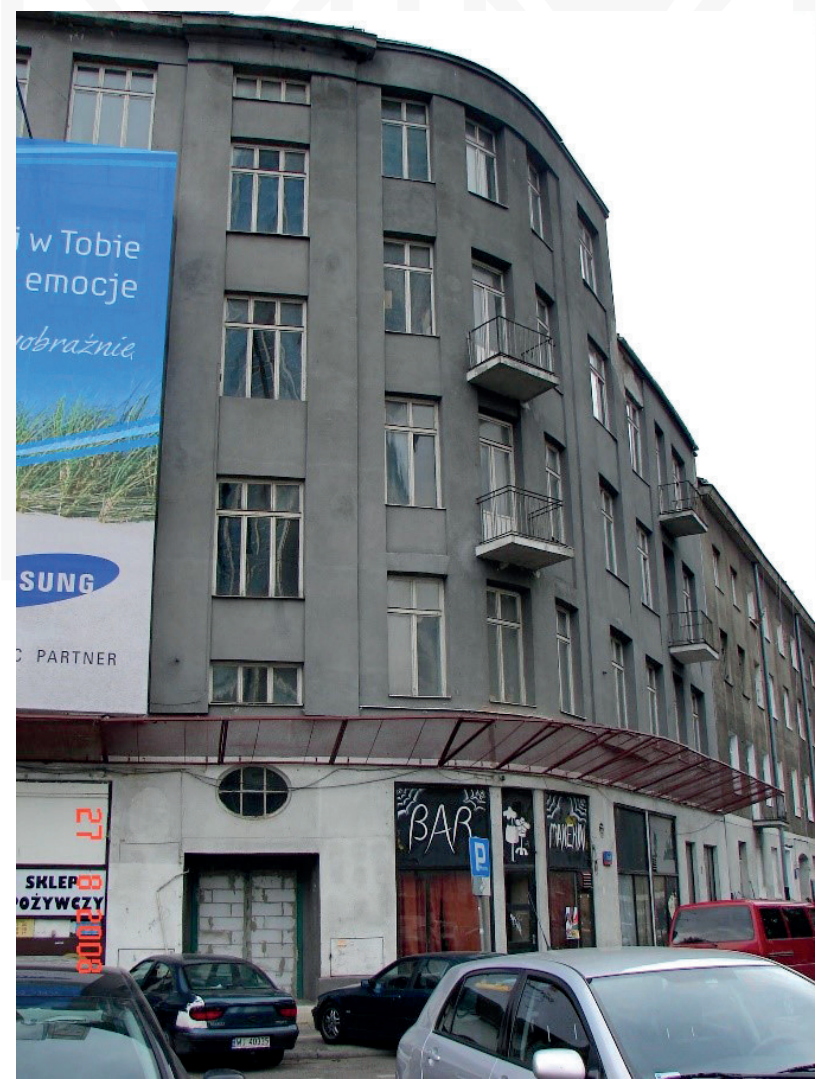

Fig. 3. View of the facade from the east 


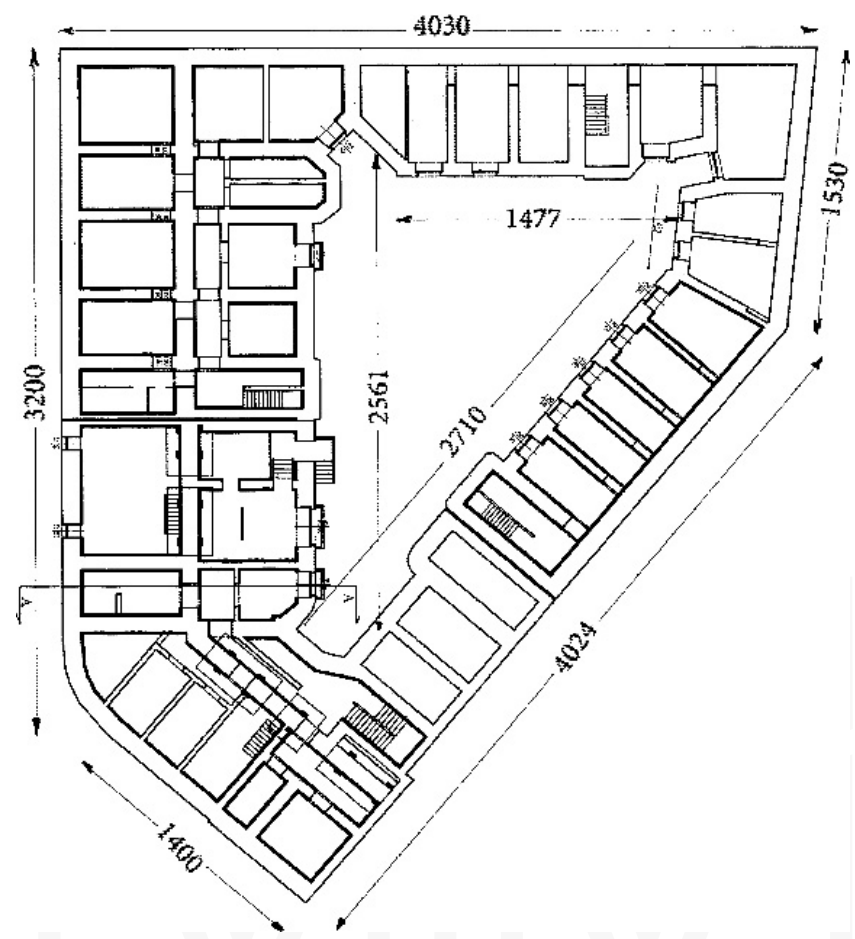

Fig. 4. Horizontal plan of building basement

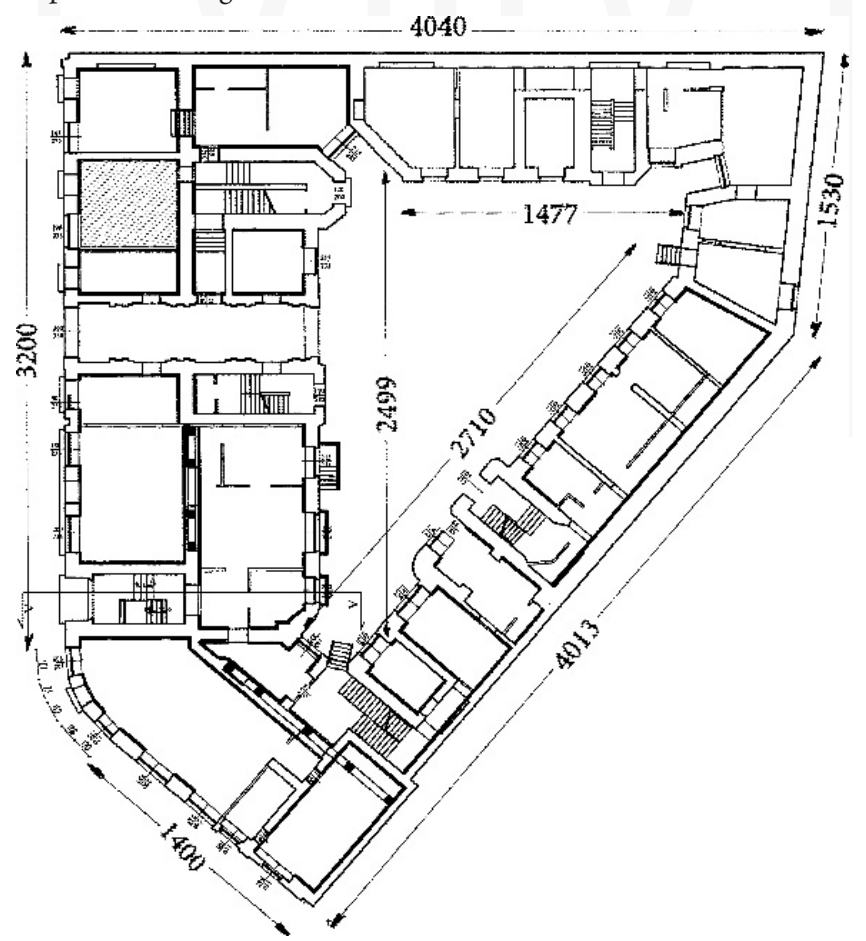

Fig. 5. Horizontal plan of the ground floor 


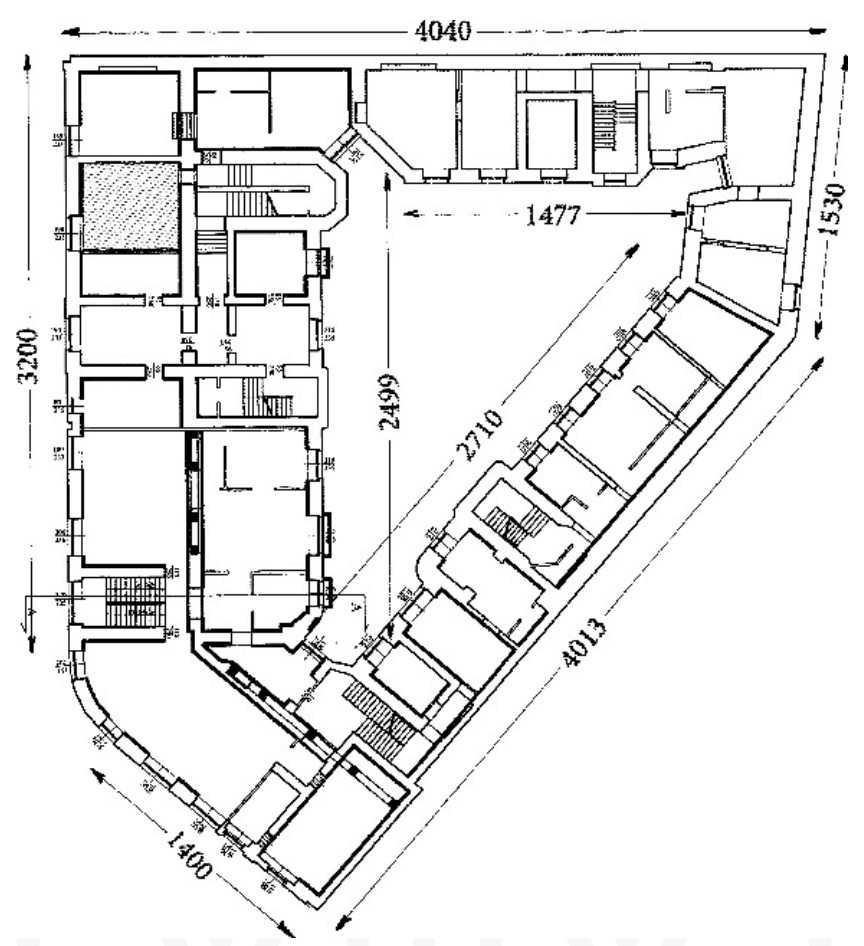

Fig. 6. Horizontal plan of the repeatable floor

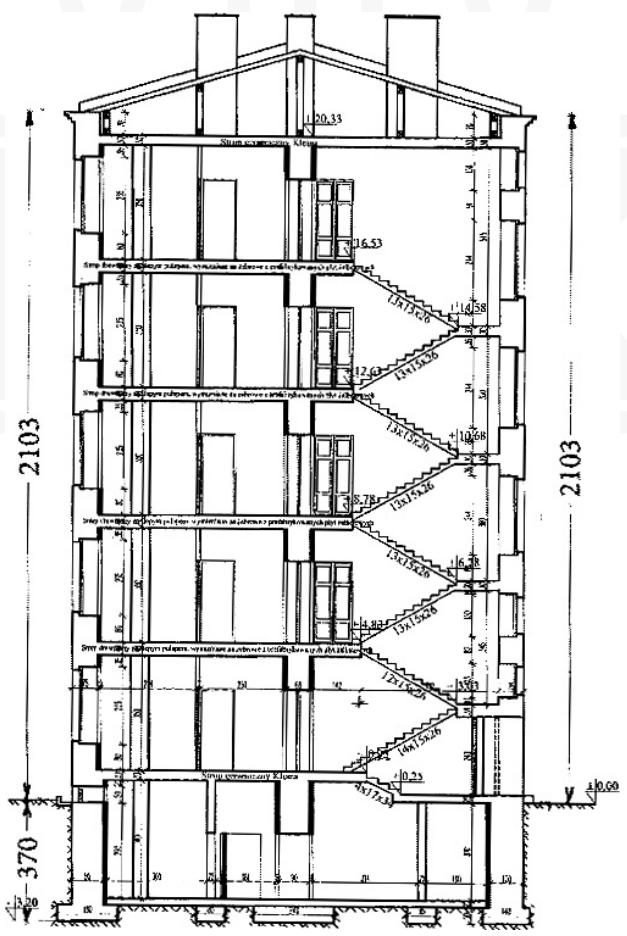

Fig. 7. Cross-section of the building 
Horizontal floor plans and vertical cross-section of the building are given in Figs. 4-7.

\section{Results of analysis}

In accordance with section C.4 of standard [2], by possessing a registered signal that has not been weighted by weighting functions $W b$ (for the vertical direction) and $W g$ (for the horizontal direction), it is possible to calculate the estimated value of the $V D V$ according to the formula:

$$
e V D V=1,4 \cdot a(t)_{R M S} \cdot t^{0,25}
$$

where:

$a(t)_{R M S}-R M S$ value weighted by weighting functions $W b$ and $W g$ according to the appropriate direction;

$t$ - the total duration of vibrations.

Five vibrograms from the measurement point $17 \mathrm{z}$ located in the middle of the ceiling on the fourth floor (see Fig. 8) were used for analysis. Measurements at this point were carried out in a vertical direction.

The excitation sources during these five measurements were: tram passing (three measurements); bus passing (one measurement); heavy truck passing (one measurement). An example of a registered signal is presented in Fig. 9 - this represents the passage of a tram on the nearest tram track.

$R M S$ of registered signal was made. RMS analysis of the signal presented in Fig. 9 is shown in Fig. 10.

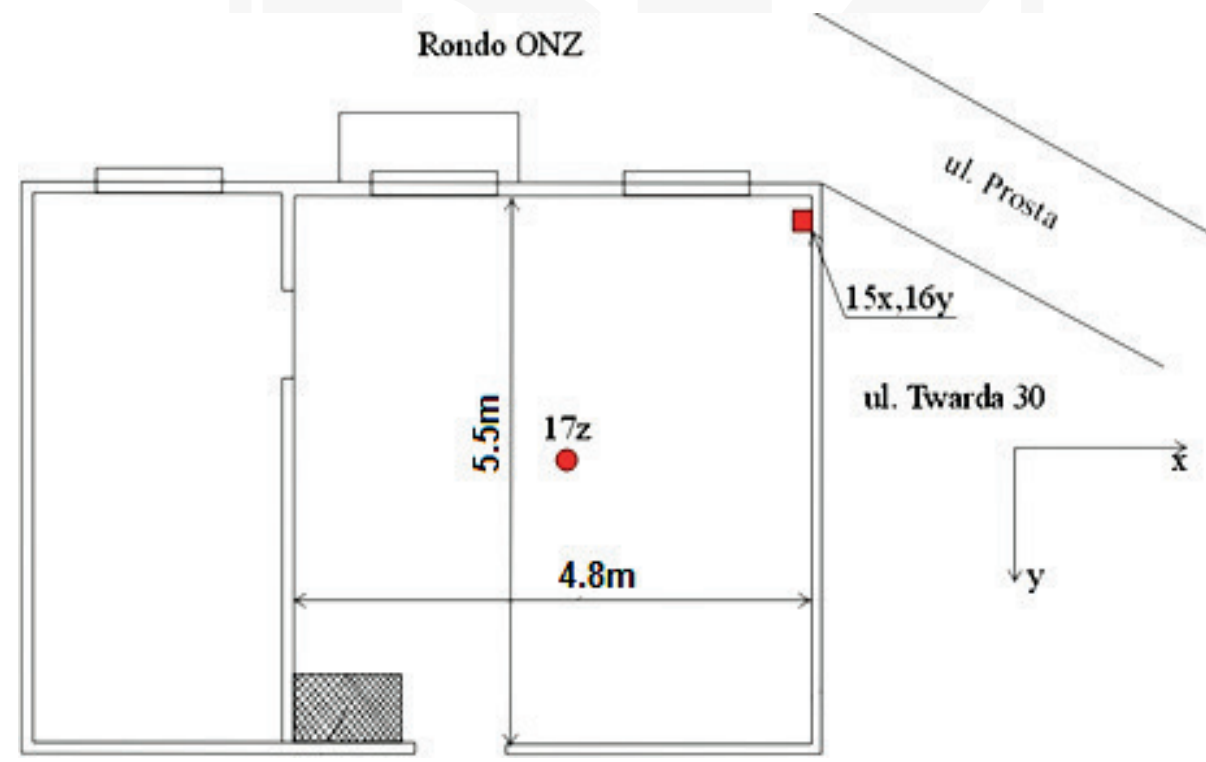

Fig. 8. Location of measurement points 
As can be seen in the above figure, according to standard [1], the threshold for the perception of vibration is exceeded, while the comfort level during night and day time is not exceeded.

From signal presented in Fig. 9, the eVDV value was then determined. The obtained $\mathrm{e} V D V$ value is 0.3 which means that (acc. Table 1 ) there is a low possibility of complaints during the daytime but complains are possible during the night. Similar analyses were made for the other four measurements and the results are listed in Table 2.

Some events can be noticed from the above Table. In almost all cases, analyses made using RMS and $V D V$ yield similar results - only in the fifth measurement are they

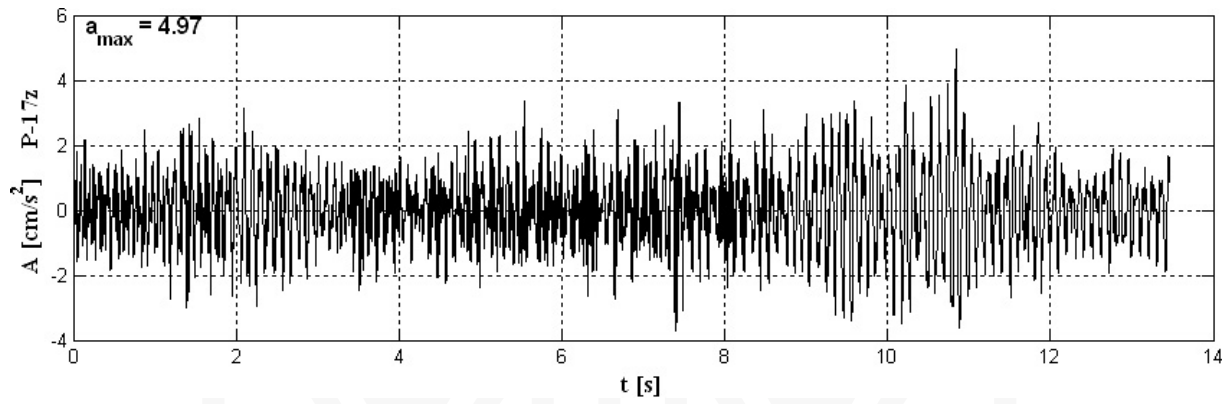

Fig. 9. The registered signal caused by tram passage

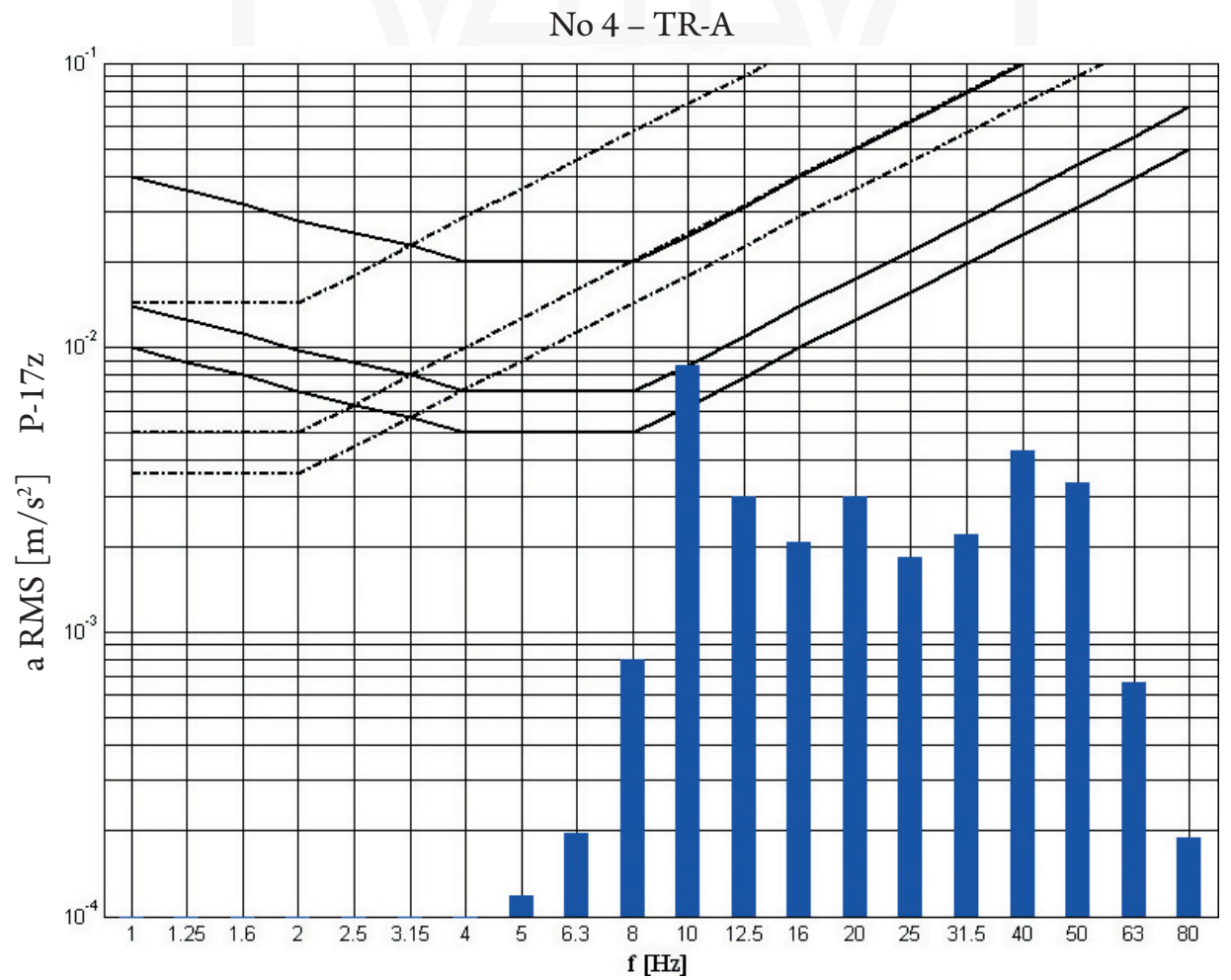

Fig. 10. RMS analysis of registered signal 
significantly different. RMS analysis infoRMS about the effects of vibrations on people while $V D V$ analysis provides information about the probabilities of complaints from residents.

Table 2. Results of comparative analysis

\begin{tabular}{|c|c|c|c|c|c|c|}
\hline \multirow{2}{*}{$\begin{array}{c}\text { Measurement } \\
\text { No. }\end{array}$} & \multirow{2}{*}{$\begin{array}{c}\text { Source } \\
\text { of vibration }\end{array}$} & \multicolumn{3}{|c|}{ RMS analysis } & \multicolumn{2}{|c|}{ eVDV analysis } \\
\hline & & WODL & $\mathrm{f}[\mathrm{Hz}]$ & comment & $\begin{array}{l}\text { VDV value } \\
{\left[\mathbf{m} / \mathbf{s}^{1,75}\right]}\end{array}$ & comment \\
\hline 1 & Bus & 1.57 & 10 & $\begin{array}{c}\text { Exceedance } \\
\text { of comfort level } \\
\text { during night }\end{array}$ & 0.404 & $\begin{array}{c}\text { complains } \\
\text { possible during } \\
\text { daytime and very } \\
\text { probable during } \\
\text { the night }\end{array}$ \\
\hline 2 & Tram & 1.39 & 10 & $\begin{array}{l}\text { Exceedance } \\
\text { of perception } \\
\text { threshold } \\
\text { of vibration but } \\
\text { comfort levels } \\
\text { not exceeded }\end{array}$ & 0.300 & $\begin{array}{l}\text { complains } \\
\text { possible during } \\
\text { night-time }\end{array}$ \\
\hline 3 & Heavy truck & 0.89 & 10 & $\begin{array}{l}\text { Perception } \\
\text { threshold not } \\
\text { exceeded }\end{array}$ & 0.180 & $\begin{array}{l}\text { Low possibility } \\
\text { of complaints }\end{array}$ \\
\hline 4 & Two trams & 1.39 & 10 & $\begin{array}{l}\text { Exceedance } \\
\text { of perception } \\
\text { threshold } \\
\text { of vibration but } \\
\text { comfort levels } \\
\text { not exceeded }\end{array}$ & 0.390 & $\begin{array}{l}\text { complaints } \\
\text { possible during } \\
\text { night-time }\end{array}$ \\
\hline 5 & Tram & 0.68 & 10 & $\begin{array}{l}\text { Perception } \\
\text { threshold not } \\
\text { exceeded }\end{array}$ & 0.313 & $\begin{array}{l}\text { complaints } \\
\text { possible during } \\
\text { night-time }\end{array}$ \\
\hline
\end{tabular}

To check the sensitivity of $V D V$ analysis on the number of different events per day, formula 4 was used:

$$
V D V_{\text {day } / \text { ight }}=\left(\sum_{n=1}^{n=N} V D V^{4}\right)^{0,25}
$$

Occurrences of forty-three tram passages were simulated with $V D V$ values varying from 0.1 to 0.4 during the daytime. The $V D V_{\text {day }}$ was determined from the above formula and is 0.781 - this means that complaints are possible. It was assumed that eighteen events of tram 
passages occurred during the night-time with $V D V$ values varying from 0.1 to 0.4 . In such cases, the $V D V_{\text {night }}$ is 0.615 which means that complaints are very probable. As can be seen, $V D V$ analysis is very sensitive to number of events occurring during the day or in the night.

\section{Conclusions}

In this paper, a comparative analysis of two different methods of assessment of the vibration influence on humans was made. Both methods, $R M S$ and $V D V$, are contained in the ISO standard [4] - the RMS method is defined as the main method and VDV as an additional method.

According to the results of analysis, it can be seen that the RMS method gives much more information about the vibrations and provides an answer not only on the exceedance of perception thresholds or comfort levels, but also in which frequency band the exceedance occurred. Therefore, $R M S$ is a much more appropriate choice to provide information to consider in the design of structures. However, it should be noticed that the RMS method takes into account the time of influence of vibration on humans only by using the "n" factor while the $V D V$ method takes the time itself by including time in the scope of integration. This is why the $V D V$ method is more sensitive to different events that can occur during the daytime or at night.

The results of analysis of single events made using both methods are similar. There are some differences but not to the extent that could be expected. For the whole day or night, the $V D V$ method is much restrictive. But it should be noted that the $R M S$ method is concerned with the vibration influence on humans while the $V D V$ values inform about the probability of complaints (low, more possible, probable) but do not provide a precise numerical value of probability.

It seems that a good direction for the evaluation method is the option contained in ISO standard [4] in which for crest factors greater than nine, more than one method of the evaluation of vibration influence on humans should be used and both main and additional methods should be reported.

\section{References}

[1] PN-88/B-02171 Evaluation of vibrations influence on people in buildings, 1988, Polish Standard [in Polish].

[2] BS 6472-1:2008 Guide to evaluation of human exposure to vibration in buildings, Part 1: Vibration sources other than blasting, 2008, British Standard.

[3] DIN 4150-2 Structural vibration, Part 2: Human exposure to vibration in buildings, 1999, German Standard.

[4] ISO 2631-2 Guide to the evaluation of human exposure to whole body vibration. Part 2 - Vibration in buildings, 2003, International Organization for Standardization. 
[5] ISO 10137 Bases for design of structures - Serviceability of buildings and walkways against vibration, 2007, International Organization for Standardization

[6] Tamura Y., Kawana S., Nakamura O., Kanda J., Nakatà S., Evaluation perception of wind-induced vibration in buildings, Structures \& Buildings, 159, 2006, 1-11.

[7] Kwok K.C.S., Hitchcock P.A., Burton M.D., Perception of vibration and occupant comfort in wind-excited tall buildings, Journal of Wind Engineering and Industrial Aerodynamics, Vol. 97, Issues 7-8, September-October 2009, 368-380.

[8] Waddington D.C, Woodcock J., Peris E., Condie J., Sica G., Moorhouse A.T., Steele A., Human response to vibration in residential environments, J. Acoust. Soc. Am. 135,82, 2014.

[9] Marioka M., Griffin M.J., Difference thresholds for intensity perception of whole-body vertical vibration: Effect of frequency and magnitude, J. Acoust. Soc. Am. 107 (1), January 2000, 620-624.

[10] Kawecki J., Stypuła K., Zapewnienie komfortu wibracyjnego ludziom $w$ budynkach narażonych na oddziatywania komunikacyjne (Ensuring vibrational comfort for people in buildings exposed for transport impact) (in Polish), Wyd. Politechnika Krakowska, Kraków 2013.

[11] Mansfield N.J., Holmlund P., Lundstrom R., Comparison of subjective responses to vibration and shock with standard analysis methods and absorbed power, Journal of Sound and Vibration, 2000, 230(3), 477-491.

[12] Gaspar C.M.R., Santosda Silva J.G., Costa-Neves L.F., Multimode, Vibration control of building steel-concrete composite floors submitted to human rhythmic activities, Computers and Structures 165, 2016, 107-122.

[13] Kawecki J., Kozioł K., Stypuła K., Wplyw konstrukcji obudowy tunelu metra na prognozowany odbiór drgań przez ludzi przebywajacych w pobliskim budynku (Influence of Metro Tunnel Structure on Prognosed Vibrations received by People Staying in Nearly Building), (in Polish), Czasopismo Techniczne, Vol.3-B/2010, 51-58. 